\title{
KINETIC STUDIES OF METHYLENE BLUE ADSORPTION ON TO ACTIVATED CARBON FROM SEA SNAIL SHELL WASTE (BITHYNIA TENTACULATA)
}

\author{
Gumus R.H ${ }^{1 *}$, Apre L ${ }^{2}$ \\ ${ }^{1,2}$ Department of Chemical and Petroleum Engineering, Niger Delta University, \\ P.M.B. 071 Bayelsa State. Nigeria.
}

\begin{abstract}
Activated carbon has been prepared from sea snail shell waste by chemical activation method using calcium chloride as activating agent. The effects of activating agent concentrations (2.5 M and $3.0 \mathrm{M})$ of calcium chloride and activation temperature $\left(700^{\circ} \mathrm{C}-900^{\circ} \mathrm{C}\right)$ were studied. The activated samples were characterized on the physical properties which showed increase with increasing temperature except for density and ash content that decreased; moisture content. A kinetic study was performed and experimental data fitted to both pseudo first and second order kinetics equation, which gave values of $k_{1}=0.115$ min and $k_{2}=0.0114 \mathrm{~min} / \mathrm{mol}$. L. The pseudo second order described better with $r^{2}=0.998$ compared to first order model and intra -particle diffusion model. The experimental data was also fitted to Langmuir, Freundlich and Nerst models. The correlation coefficient of Langmuir model was higher $r^{2}=0.998$ compared to Freundlich and Nerst showing monolayer adsorption. The adsorption capacity $q_{\max }$ and $n$ values were also determined; 0.752 and 1.656 respectively. Iodine number was also determined which is an equivalent to surface area of the activated carbon available for the adsorption of ions in aqueous solution. There was no marked difference in the result with varying activating agent concentrations.
\end{abstract}

\section{KEYWORDS:}

Pseudo Kinetic Studies, Activated carbon, Sea Snail Shell, Adsorption

\section{INTRODUCTION}

Activated carbons form a large and important class of porous solids, which have found a wide range of technological applications [1]. The characteristics and structural properties of activated carbon depend on the physical and chemical properties of the precursor, method of activation, oxidizing agent, time and temperature employed. Activated carbons are carbonaceous material that can be distinguished from elemental carbon by the oxidation of the carbon atoms found on the inner and outer layers [2]. These materials are characterized by their large surface area, porous surface containing functional group. For this reason, activated carbons are widely used as adsorbents for the removal of organic chemicals and pollutant from air, gases, portable water and also in wastewater treatment [3]. The surface oxygen functional groups can be easily introduced to the carbon by different activation methods including dry and wet oxidizing agents. Wet oxidation methods involve the reaction between the carbon surface and solutions of oxidizing agents such as phosphoric acid $\left(\mathrm{H}_{3} \mathrm{PO}_{4}\right)$, Nitric acid $\left(\mathrm{HNO}_{3}\right)$, Zinc chloride $\left(\mathrm{ZnCl}_{2}\right)$, Potassium hydroxide $(\mathrm{KOH})$, Potassium permanganate $\left(\mathrm{KMnO}_{4}\right)$, Calcium chloride $\left(\mathrm{CaCl}_{2}\right)$ etc. One of the fastest growing areas is the environmental application of activated carbon to treat effluent from textile industry. These effluent when discharged, defaces the look of natural water and highly toxic [4], also causes harm to mammalian cells by causing kidney tumors [5, 6]. Many treatment methods have been employed to remove dyes from wastewater; using physical and chemical methods [7] which are considered expensive in terms of energy and reagents consumption [8,9].

DOI : 10.14810/ijamse.2016.5105 
In recent times, the interest in the production of activated carbon from agricultural waste cannot be over emphasized; an added value to waste. Several substances have been screened as alternative to conventional raw materials for the production of activated carbon which include; palm seed coat [10], coconut shells [11], sepiolite pellet [12], and bamboo stem wastes[13] tridax procumbens 14], olive stones [15], cow bone [16], land snail shell [17], orange waste [18], terminalia arjuna nuts [19], euphorbia antiquorum L[20], periwinkle shell [21]. The present study will consider sea snail shell to produce activated carbon for the adsorption of model solution of standard dye (methylene blue) for kinetic study.

\section{MATERIALS AND METHOD}

\subsection{Materials}

Sea snail shell precursors were supplied by Amassoma traders, Bayelsa state. Other materials include, calcium chloride dihydrate $\left(\mathrm{CaCl}_{2}\left(\mathrm{OH}_{2}\right)_{2}\right)$ laboratory standard reagent, distilled water and Equipments include: weighing balance, (Denver Instrument Vecstar Muffle Furnace, Oven (Thermostatic Drying Oven DHG-9202), desiccators, pH meter, UV spectrophotometer and Moisture analyzer.

\subsection{Cabonization}

Fresh sea snail shells were washed with di-ionized water, sun dried for 24 hours to drain off water and further dried in an oven at $105^{\circ} \mathrm{C}$ to complete dryness. The dried shells were crushed into smaller sizes and stored in air tight container for the carbonization process. The dried samples were carbonized using the Vecstar Muffle Furnace at high temperatures of $700^{\circ} \mathrm{C}, 800^{\circ} \mathrm{C}$, and $900^{\circ} \mathrm{C}$ for 3 hours 30 minutes due to the hard nature of the precursor and cooled to room temperature, stored in discicator for the activation.

\subsection{Chemical activation.}

$50 \mathrm{~g}$ of the carbonized sample was mixed with $0.053 \mathrm{~L}$ of $2.5 \mathrm{M}$ calcium chloride solution in a beaker. The mixture was left for 5 minutes to allow escape of gases formed in the exothermic reaction before covering with a lid and left for 24 hours. The activated carbon was filtered out, washed with di-ionized water to remove any residual chemical and allowed to be drained completely. The sample was dried in oven at $105^{\circ} \mathrm{C}$ for 1 hour 25 minutes. The same process was repeated with $3.0 \mathrm{M}$ of calcium chloride. The activation temperatures were $700^{\circ} \mathrm{C}, 800^{\circ} \mathrm{C}$, and $900^{\circ} \mathrm{C}$. For easy description samples were identified as 1A700, 1B800, 1C900 and 2A700, 2B800, 2C900 for concentrations of $2.5 \mathrm{M}$ and 3.0 M respectively.

\subsection{Characterization}

Characterization of samples were carried out on pore volume, porosity, moisture Content, Ash Content, $\mathrm{pH}$, bulk density and iodine number described earlier [16].

\subsection{Batch adsorption study}

The batch adsorption study was conducted on activated carbon using methylene blue by varying the dosage of activated carbon. $5 \%$ solution of methylene blue was prepared and mixed with distilled water up to $0.1 \mathrm{~L}$. The activated carbon 1C900 and 2C900 with high pore volume and porosity were used for the adsorption study. A kinetic study was carried out with $0.5 \mathrm{~g}$ of the activated carbon sample on methylene blue solution with an interval of 30 minutes and solution of methylene blue was withdrawn for the kinetic study. 
The quantity of sample was varied from $0.5 \mathrm{~g}$ to $2.5 \mathrm{~g}$ of activated carbon and was added into $0.02 \mathrm{~L}$ of the methylene blue solution and mixed thoroughly by shaking it in 8 minutes and left for 1 hour to settle. The solution was filtered using a filter paper and the filtrate was analyzed using UV spectrophotometer with a wave length of $640 \mathrm{~nm}$. The amount adsorbed at equilibrium, $q_{e}\left(\mathrm{mg} \mathrm{g}^{-1}\right)$, was calculated by

$$
q_{e}=\frac{\left(C_{0}-C_{e}\right) V}{1000 W}
$$

where $\mathrm{C}_{0}$ and $\mathrm{C}_{\mathrm{e}}\left(\mathrm{mg} \mathrm{l}^{-1}\right)$, are the liquid-phase concentration of methylene blue at initial and final equilibrium respectively. $\mathrm{V}$ is the volume of the solution (liter), and $\mathrm{W}$ is the mass of the dry adsorbent used (g).

\subsection{Iodine number}

$50 \mathrm{mg}$ of activated carbon was placed in a $0.025 \mathrm{~L}$ conical flask and $0.02 \mathrm{~L}$ of the reagent was transferred quantitatively into the flasks followed by addition of $0.015 \mathrm{~L}$ of chloroform. The flask and its content were kept in the dark in a laboratory cupboard for 11 hours for halogenation to take place. $0.01 \mathrm{~L}$ of saturated potassium iodide was added to each flask. The burette was then filled to the $0.05 \mathrm{~L}$ mark with $0.1 \mathrm{M}$ solution of sodium thiosulphate. $0.05 \mathrm{~L}$ of distilled water was further added to the flask and titrated against the thiosulphate until the solution turns pale yellow. 3 drops of freshly prepared starch indicator was added which turns blue into black. The titration continued until the solution turns colorless. A blank titration was also conducted with chloroform.

Iodine number was calculated using the formula:

$$
\text { Iodine No }=\frac{(B-S) * M * 12.69}{\text { sample weight }}
$$

where $\mathrm{B}=$ blank titration, $\mathrm{S}=$ sample $\mathrm{M}=$ molarity of thiosulphate, 12.69 was used as conversion from meq thiosulphate to $\mathrm{g}$ iodine, $\mathrm{M} . \mathrm{W}$ iodine $=127.9$

\section{RESULTS AND DISCUSSION}

\subsection{Characterization of activated carbon}

The properties of the characterized sample are presented in Table 1 . The $\mathrm{pH}$ value of activated carbon is a measure of acidity or basicity which influences adsorption by affecting the surface properties of the adsorbents and ionization or dissociation of the adsorbate molecules. At higher $\mathrm{pH}$ value, dye adsorbed on the adsorbent surface can decrease considerably. For colour adsorption, its efficiency decreases in an alkaline medium. As can be seen in Table 1, the activated carbon produced with the impregnation of $2.5 \mathrm{M}$ and $3.0 \mathrm{M} \mathrm{CaCl}_{2}$ fall within an alkaline range (8.49 - 8.60). In sugar decolourization, a distinctive acidic activated carbon may cause inversion of sucrose while alkaline can cause degradation or organic impurities. Hence, an activated carbon with $\mathrm{pH}$ value range 6-9, has found to be acceptable for most applications [20, 22]. Density is also important in many industrial applications, especially in sugar decolourization where high viscosity syrup is displaced through a column of activated carbon. The density obtained ranges from $2.5-0.7 \mathrm{mg} / \mathrm{L}$ comparable to work reported in literature [23] 
The ash content is a residue, inorganic, inert and unusable part present in the activated carbon when these are burnt off. The ash content consists mainly of aluminum, iron, silica, magnesium, and calcium. The lower the ash content, the better the activated carbon. Sample C1900 and C2900 have relatively lower ash content (40.50 -37.00). The ash content decreased with the increase in temperature. The moisture content obtained was 0.22 and 0.24 for samples $1 \mathrm{C} 900$ and 2C900 comparable to results reported in literature [22] using Delonix regia fruit pod $(0.22 \pm 0.14)$. The pore volume also increased with increase in temperature. A similar trend was observed with $\mathrm{CaCl}_{2}$, where there was also an increase in pore volume as the temperature was increased from $700^{\circ} \mathrm{C}$ to $900^{\circ} \mathrm{C}[17]$.

Table 1: Physical properties of activated carbon impregnated with $\mathrm{CaCl}_{2}$

\begin{tabular}{|l|l|l|l|l|l|l|}
\hline $\begin{array}{l}\text { Temperature } \\
(\mathbf{0} \mathbf{c})\end{array}$ & $\mathbf{p H}$ & $\begin{array}{l}\text { Bulk } \\
\mathbf{d e n s i t y} \\
(\mathbf{m g} / \mathbf{L})\end{array}$ & $\begin{array}{l}\text { Ash } \\
\mathbf{c o n t e n t} \\
(\mathbf{\%})\end{array}$ & $\begin{array}{l}\text { Moisture } \\
\text { content } \\
(\mathbf{\%})\end{array}$ & $\begin{array}{l}\text { Pore } \\
\text { volume } \\
\left(\mathbf{m}^{\mathbf{3}}\right)\end{array}$ & Porosity \\
\hline $\begin{array}{l}1 \mathrm{~A}(700) \\
2.5 \mathrm{M}\end{array}$ & 8.49 & 2.50 & 43.50 & 0.80 & 0.28 & 0.156 \\
\hline $1 \mathrm{~B}(800)$ & 8.54 & 1.25 & 41.50 & 8.00 & 0.38 & 0.19 \\
\hline $1 \mathrm{C}(900)$ & 8.60 & 0.714 & 40.50 & 11.00 & 0.80 & 0.314 \\
\hline $\begin{array}{l}2 \mathrm{~A}(700) \\
3.0 \mathrm{M}\end{array}$ & 8.58 & 2.00 & 43.00 & 1.00 & 0.25 & 0.139 \\
\hline $2 \mathrm{~B}(800)$ & 8.56 & 1.429 & 38.00 & 10.00 & 0.42 & 0.21 \\
\hline $2 \mathrm{C}(900)$ & 8.58 & 1.042 & 37.00 & 12.00 & 0.77 & 0.275 \\
\hline
\end{tabular}

\subsection{Effect of dosage of activated carbon}

The effectiveness of activated carbon is specified by the amount of substance it can adsorb per unit weight of activated carbon. This is helpful in model prediction for analysis and design of an adsorption process. Figure 1 shows that the percentage removal of methylene blue increased with increase in adsorbent dose. The adsorption of adsorbate increases with an increase in the availability of more adsorption sites resulting from the increased adsorbent dose [24]. The initial uptake of adsorbate was about $80 \%$ at optimum adsorbent value of $0.5 \mathrm{~g}$. The percent uptake remained constant with the increase in amount of dosage. This can be attributed to saturated sites which could no longer accommodate adsorbate molecules. Varying the reagent concentration did not affect the percentage removal of methylene blue. 


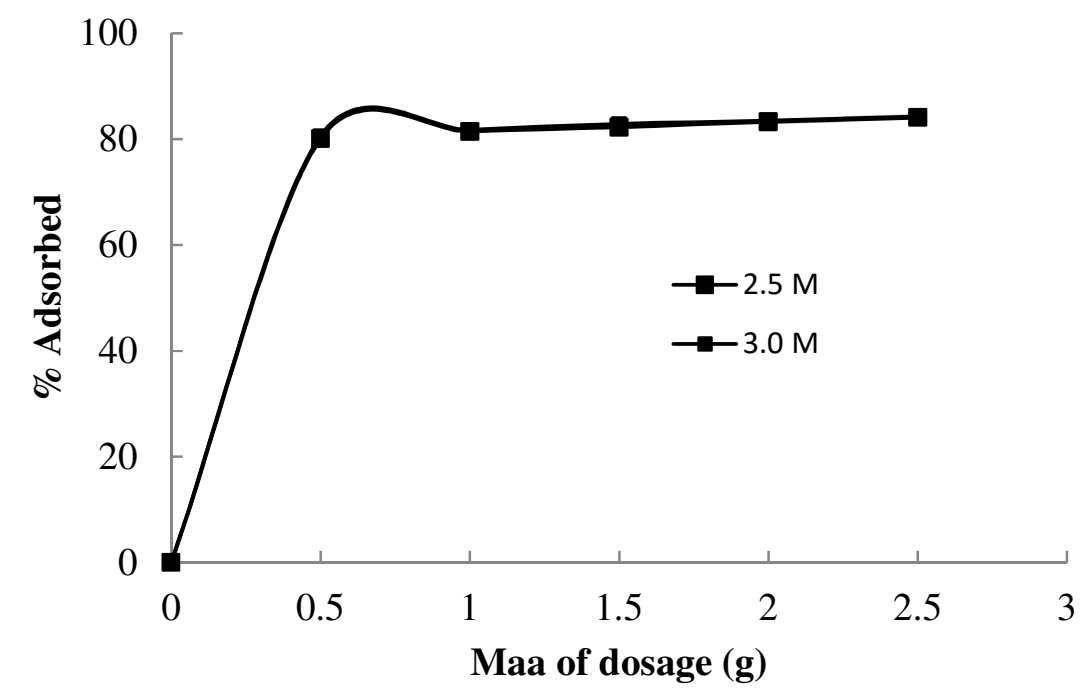

Figure 1.\% Adsorbed of Methylene Blue on to 1C900 and 2C900 at various concentration of activation reagent; Adsorbent dosage $0.5 \mathrm{~g}$ to $2.5 \mathrm{~g}$

\subsection{Kinetics studies}

The factors that control the rate and mechanism of adsorption are physical and/or chemical properties of adsorbent, ambient temperature, solution $\mathrm{pH}$ and nature of absorbate [20]. The kinetic models proposed by research groups are useful for design and optimization of effluent treatment processes. The models considered to study the mechanism of methylene blue adsorption on to activated carbon prepared from sea snail shell are: pseudo first order, pseudo second order and intra-particle diffusion.

The proposed pseudo first order kinetic model [19] with the linear form is given as

$$
\ln \left(q_{e}-q_{t}\right)=\ln q_{e}-\frac{k_{1}}{2.303} t
$$

$\mathrm{k}_{1}$ is rate constant, $q_{e}$ and $q_{t}$ are the amount of methylene blue adsorbed at equilibrium and time (min), respectively. The values of $\mathrm{k}_{1}$ and $\mathrm{q}_{\mathrm{e}}$ were determined from the linear plot of $\ln \left(q_{e}-q_{t}\right)$ versus $\mathrm{t}$ from the slope and intercept (Figure not shown). The rate constant $\mathrm{k}_{1}$ was found to be 0.115 min with correlation coefficient of 0.817 . The $r^{2}$ value, .> 0.8 and $60 \%$ deviation between the experimental and calculated adsorption capacities $\mathrm{q}_{\mathrm{e}}$ exp and $\mathrm{q}_{\mathrm{e} \text { cal }}$ suggest that the adsorption data fitted poorly to pseudo first order kinetics.

\subsubsection{Pseudo Second order kinetics}

The linearized form of the pseudo second-order model based on equilibrium adsorption is expressed as:

$$
\frac{t}{q_{t}}=\frac{1}{k_{2} q_{e}^{2}}+\left(\frac{1}{q_{e}}\right) t
$$


Where $k_{2}(\mathrm{~g} / \mathrm{mg} \mathrm{min})$ is the rate constant of the pseudo second order model, the initial adsorption rate, $\mathrm{h}(\mathrm{mg} / \mathrm{g} \cdot \mathrm{min})$ as $\mathrm{t}$ approaches zero can be defined as $h=k_{2} q_{e}^{2}$. Figure 2 shows the pseudo second order plot for the adsorption of methylene blue by SSSAC and the results are presented in Table 2 . The $\mathrm{q}_{\mathrm{e}}$ and $\mathrm{k}_{2}$ values can be determined from the slope and intercept of the plot between $\frac{t}{q_{e}}$ and $t$. The theoretical values of of the adsorption capacities $\mathrm{q}_{\mathrm{e}}$ of the kinetic model were compared to the actual value which is presented in Table 2. It can be observed that the actual value is closer to the theoretical value obtained with pseudo second order; $11.28 \mathrm{mg} / \mathrm{g}$ and $12.82 \mathrm{mg} / \mathrm{g}$ respectively. A deviation of $5.6 \%$ less than that obtained with pseudo first order kinetics. The rate constant $\mathrm{k}_{2}$ was found to be $1.142 \times 10^{-2} \mathrm{~g} / \mathrm{mg}$.min with the highest correlation coefficient of 0.998 . The initial adsorption rate $\mathrm{h}$, was determined to be $1.67 \mathrm{x}$ $10^{-3} \mathrm{mg} / \mathrm{g}$.min. The result showed that pseudo second order kinetics describes the adsorption of methylene blue onto the activated carbon and it is chemical adsorption that is said to be the slowest mechanism [25].

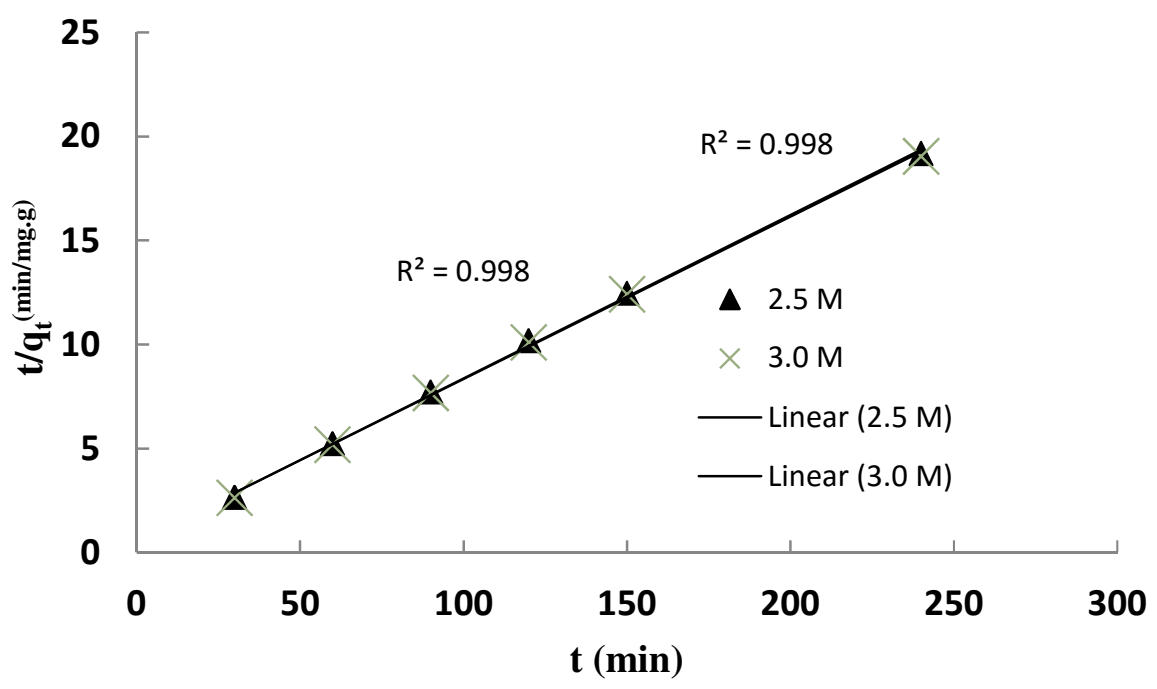

Figure 2. Pseudo second order kinetics for adsorption of methylene blue on to 1C900 and 2C900; Adsorbent dosage, $0.5 \mathrm{~g}$

\subsubsection{Intra particle diffusion model}

In adsorption process, initial adsorption occurs on the surface of the adsorbent but there is also possibility of the adsorbate to diffuse into interior pores of the adsorbent. A proposed kinetic model [26] suggesting if the adsorption is intra particle diffusion exists is given in equation 6 .

$$
q_{e}=k_{d} t^{1 / 2}
$$

Where $\mathrm{k}_{\mathrm{d}}$ is the intra particle diffusion rate constant, which is determined by the plot of $\mathrm{q}_{\mathrm{e}}$ versus $\mathrm{t}^{1 / 2}$ (See Figure 3) and the results are presented in Table 2. The intra particle diffusion rate constant was found to be 0.119 , with a correlation coefficient $r^{2}$ ranging from 0.963 to 0.966 . As can be seen, the linear plot did not pass through the origin which may be due to the variation of mass transfer in the initial and final stages of adsorption [27]. This deviation and the high 
correlation coefficient indicates that pore diffusion may be the controlling step and play a major role for the adsorption of methylene blue by the activated carbon prepared [20].

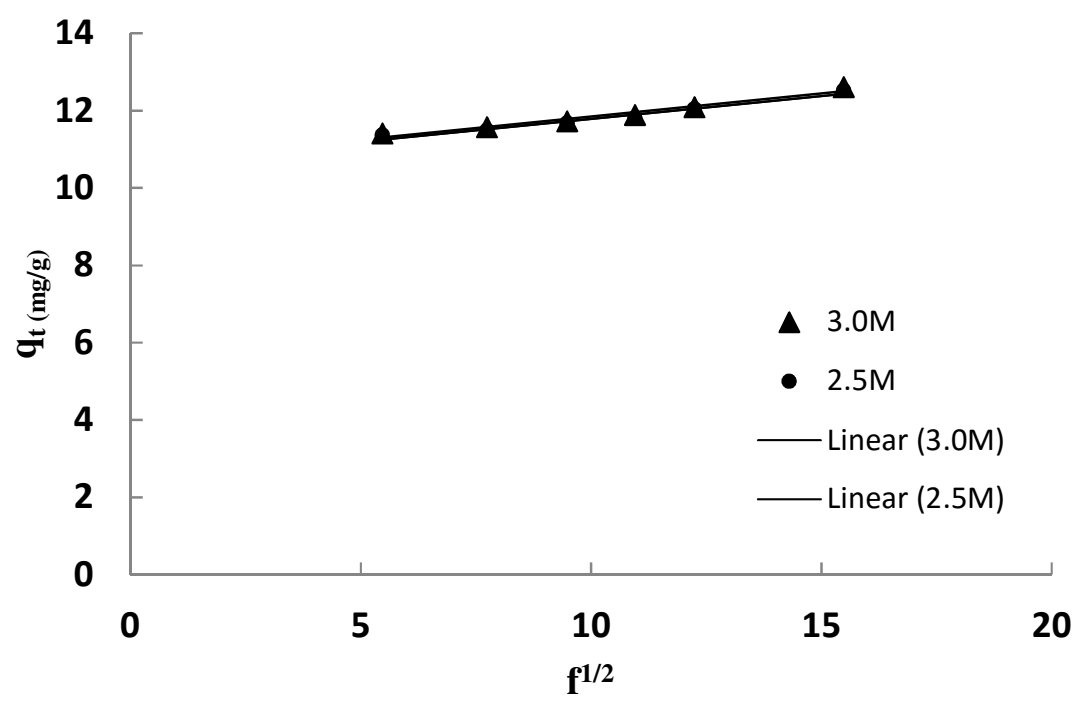

Figure 3 Intra particle diffusion plot for the adsorption of methylene blue on to 1C900 and 2C900; adsorbent dosage, $0.5 \mathrm{~g}$

\subsection{Isotherm studies}

The adsorption isotherm data were fitted to both the Langmuir, Freudlich and Nerst models. The linearized plots are shown in Figures 4, 5 and 6 respectively.

\subsubsection{Langmuir Isotherm model}

The linear form of Langmuir's isotherm model is given in equation 7.

$$
\frac{c_{e}}{q_{e}}=\frac{1}{q_{\max }} k_{L}+\frac{1}{q_{\max }} c_{e}
$$

Where

$\mathrm{C}_{\mathrm{e}}$ is the equilibrium concentration of the adsorbate (Methylene blue) (mg/l), $\mathrm{q}_{\mathrm{e}}$ is the amount of adsorbate adsorbed per unit mass of adsorbate $(\mathrm{mg} / \mathrm{l}), \frac{1}{q_{\max }} k_{L}$ is the intercept which is related to monolayer adsorption of adsorbent towards adsorbate., 1/q max is the slope obtained from the plot of $\mathrm{C}_{\mathrm{e}} / \mathrm{q}_{\mathrm{e}}$ vs $\mathrm{C}_{\mathrm{e}}$, shown in Figure $4 . \mathrm{K}_{\mathrm{L}} / \mathrm{q}_{\max }$ and $1 / \mathrm{q}_{\max }$ were calculated from the plot. The values are presented in Table 2 . The $\mathrm{q}_{\max }$ is related to adsorption capacity, $(\mathrm{mg} / \mathrm{g})$ while $\mathrm{K}_{\mathrm{L}}$ is the energy of adsorption $(\mathrm{L} / \mathrm{mg})$ and these values were determined from the slope and intercept of the linearized plot shown in Figure 4. The $\mathrm{q}_{\max }$ was found to range from $0.752 \mathrm{mg} / \mathrm{g}$ to 0.805 $\mathrm{mg} / \mathrm{g}$, comparable with values in literature (0.2191-0.0558) for adsorption of lead from industrial wastewater onto commercial activated carbon and periwinkle shells [21]. 
A high correlation coefficient value greater than $>0.9$ was obtained, indicating a better fit to the experimental data. Similar results have been found in literature in the adsorption of methylene blue by coconut shell activated carbon [28].

The essential characteristics of Langmuir isotherm which is expressed by a dimensionless separation factor $R_{L}[29]$ is given as:

$$
R_{L}=\frac{1}{\left(1+K_{L} C_{0}\right)}
$$

The value of $R_{L}$ indicates the nature of the adsorption process, $R_{L}>1$ unfavourable, $R_{L}=1$ Linear, $0<\mathrm{R}_{\mathrm{L}}<1$ favorable, and $\mathrm{R}_{\mathrm{L}}=0$ irreversible, Where $\mathrm{K}_{\mathrm{L}}$ is the Langmuir constant and $\mathrm{C}_{0}$ is the initial concentration of adsorbate $(\mathrm{mg} / \mathrm{L})$. The $\mathrm{R}_{\mathrm{L}}$ value was found to range from 0.014 to 0.013 which indicates a favorable adsorption process. The increase in concentration of activating reagent from $2.5 \mathrm{M}$ to $3.0 \mathrm{M}$ decreases the values of both $\mathrm{R}_{\mathrm{L}}$ and $\mathrm{K}_{\mathrm{L}}$. The $\mathrm{K}_{\mathrm{L}}$ value was found to vary from 75.5 to 72.3 .

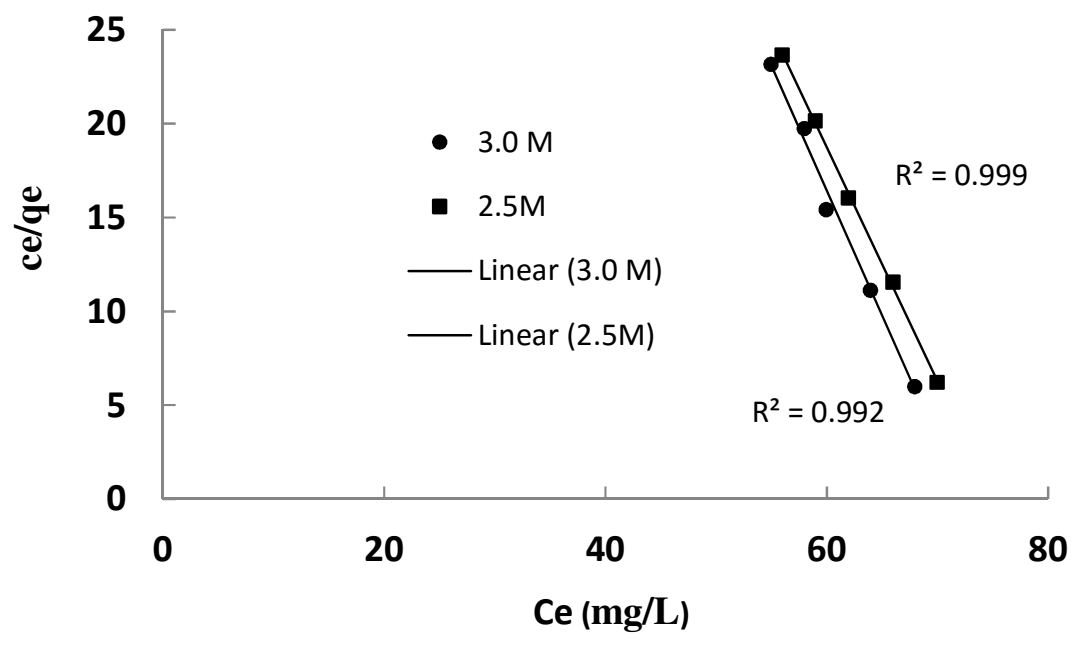

Figure 4 Langmuir isotherm for the adsorption methylene blue on to $1 \mathrm{C} 900$ and 2C900 at various concentration of activation reagent, Adsorbent dosage , $0.5 \mathrm{~g}$

\subsubsection{Freundlich isotherm}

The well known logarithmic form of Freundlich model is given by the following equation

$$
\log q_{e}=\log K_{f}+\frac{1}{n} \log C_{e}
$$

Where $q_{e}$ is the amount adsorbed at equilibrium $(\mathrm{mg} / \mathrm{g}), C_{e}$ is the equilibrium concentration of the adsorbate. $K_{f}$ is the adsorption capacity of the adsorbent. $\left(\mathrm{mg} / \mathrm{g}^{-1}\right)\left(\mathrm{mg}^{-1}\right)^{1 / \mathrm{n}}, \mathrm{n}$ indicates how favourable the adsorption process is, $\frac{1}{n}$ is the slope, ranging between o and 1; a measure of adsorption intensity or surface heterogeneity, becoming more heterogeneous as its value gets closer to zero. The values can be calculated from the slope and intercept of the plot log $\mathrm{q}_{\mathrm{e}}$ versus $\log \mathrm{C}_{\mathrm{e}}$. The $\mathrm{K}_{\mathrm{f}}$ and $\mathrm{n}$ values were found to be 3.48 and 1.656, with the sample activated with concentration of $2.5 \mathrm{M}$. The result is comparable to values obtained by activated carbon prepared from sugarcane and chelex [30]. The $\mathrm{n}$ values between 1 and 10 represent beneficial adsorption $[20$,$] . The value of n$ being greater than 1.0, indicates that the adsorption of methylene blue on to 
1C900 and 2C900 the process is beneficial. Freundlich model fits well to data at higher and intermediate concentrations because the equation does not approach Henry's Law of ideal dilute solutions [20].

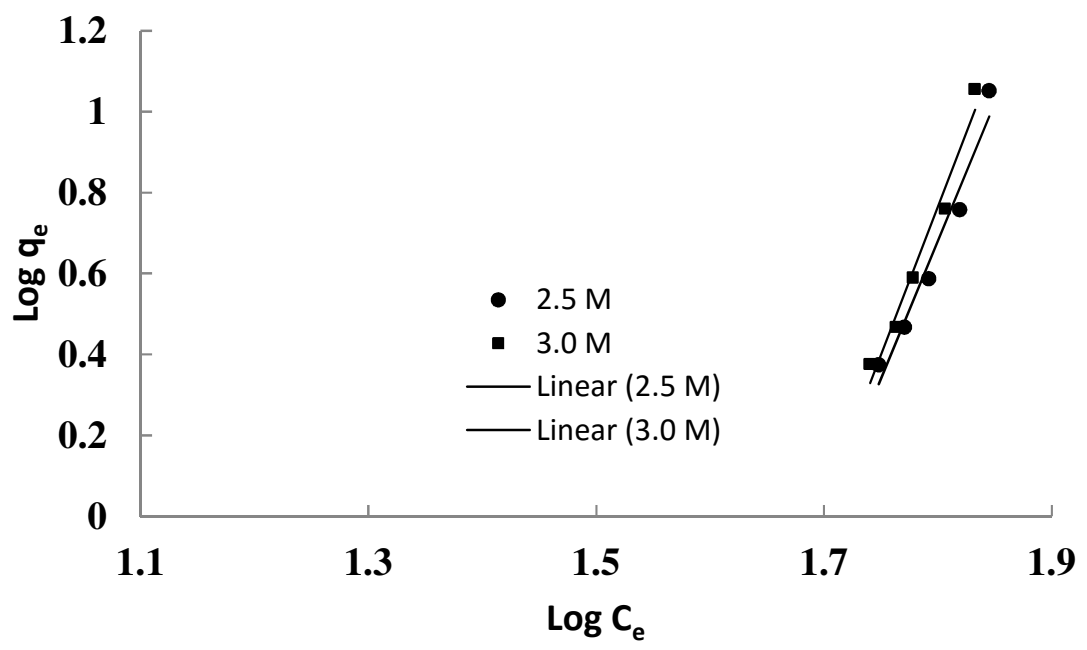

Figure 5 Freundlich isotherm for the adsorption of methylene blue on to $1 \mathrm{C} 900$ and 2C900 at various concentration of activation reagent, Adsorbent dosage, $0.5 \mathrm{~g}$

\subsubsection{Nerst Model}

The Nerst equation is characterized by only one constant, $\mathrm{K}_{\mathrm{p}}$ the partition ratio, also called the distribution coefficient which can determine from equation 10 .

$$
q_{e}=k_{p} c_{e}
$$

Nesrt isotherm can be used to describe the distribution of a solute between two immiscible solvent; similar to the situation where the absorbate dissolves in the solid adsorbent [31]. The partition ratio is used to compute the standard affinity of adsorption given in equation 11.

$$
\Delta \stackrel{o}{U}=-R T \ln K_{p}
$$

Where $\mathrm{R}$ is the gas constant and $\mathrm{T}$ is the absolute temperature.

The partition constant for the adsorption of methylene blue by 1C900 and 2C900 is presented in Table 3. The partition constant ranges from 0.671 to 0.604 , with coefficient values of $R^{2}>0.8$. The standard affinity of adsorption was found to be positive; 1.22 and 0.96 . Similar results were reported [32], where a partition value of 0.726 was recorded using activated carbon prepared from biopolymer chitin to adsorb xylenol orange whilst 9.571 and 8.784 were obtained by [33] with ACZN and ACSN respectively. 
International Journal of Advances in Materials Science and Engineering (IJAMSE) Vol.5, No.1, January 2016

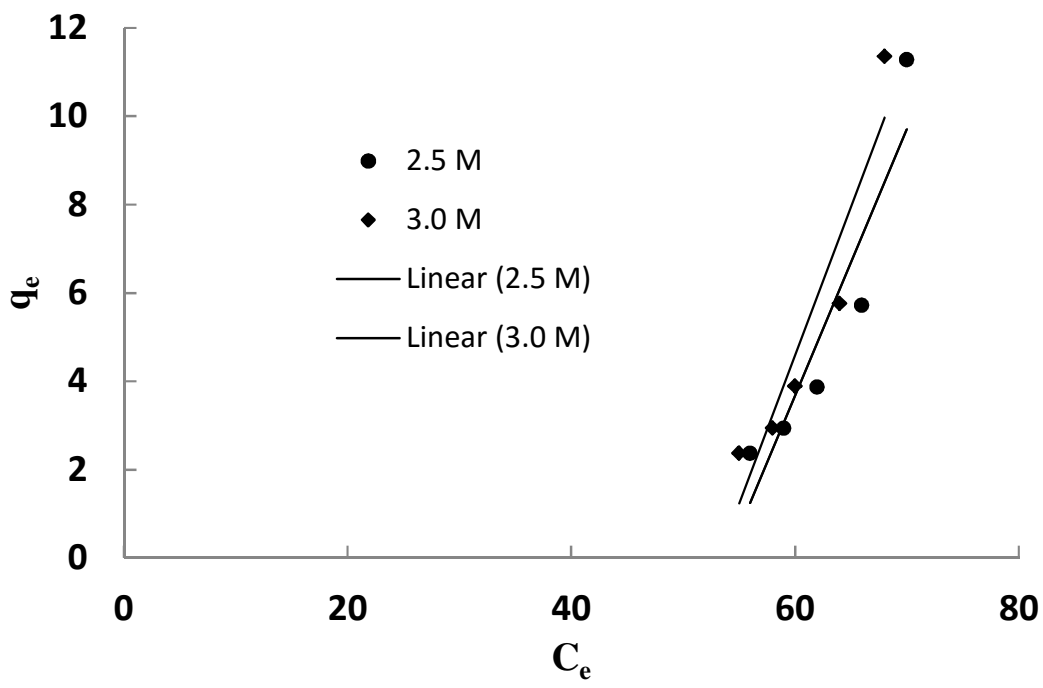

Figure 6 Nerst isotherm for adsorption of methylene blue on to 1C900 and 2C900 at various concentration of activation reagent, Adsorbent dosage, $0.5 \mathrm{~g}$

Table 2 Calculated kinetic parameter for the adsorption of methylene blue on 1C900 and 2C900

\begin{tabular}{|l|l|l|}
\hline \multicolumn{1}{|c|}{ Concentration (M) } & $\mathbf{2 . 5}$ & $\mathbf{3 . 0}$ \\
\hline Pseudo first order kinetics & & \\
\hline $\mathrm{k}_{1}\left(\mathrm{~min}^{-1}\right)$ & 0.115 & 0.115 \\
\hline $\mathrm{q}_{\mathrm{e}}$ cal $(\mathrm{mg} / \mathrm{g})$ & 4.618 & 4.845 \\
\hline $\mathrm{q}_{\mathrm{e}} \exp (\mathrm{mg} / \mathrm{g})$ & 11.28 & 11.36 \\
\hline $\mathrm{r}^{2}$ & 0.817 & 0.817 \\
\hline Pseudo second order kinetics & & \\
\hline $\mathrm{k}_{2}$ & 0.0114 & 0.0113 \\
\hline $\mathrm{q}_{\mathrm{e}}$ cal & 12.82 & 12.82 \\
\hline $\mathrm{r}^{2}$ & 0.998 & 0.998 \\
\hline Intra particle diffusion model & & \\
\hline $\mathrm{K}_{\mathrm{d}}(\mathrm{mg} / \mathrm{g} \cdot \mathrm{min})$ & 0.119 & 0.117 \\
\hline $\mathrm{r}^{2}$ & 0.966 & 0.963 \\
\hline
\end{tabular}


Table 3 Results of various isotherm plots for the adsorption methylene blue on to $1 \mathrm{C} 900$ and $2 \mathrm{C} 900$

\begin{tabular}{|l|l|l|}
\hline Concentration (M) & $\mathbf{2 . 5}$ & $\mathbf{3 . 0}$ \\
\hline Langmuir model & & \\
\hline $\mathrm{q}_{\max }(\mathrm{mg} / \mathrm{g})$ & 0.752 & 0.805 \\
\hline $\mathrm{K}_{\mathrm{L}}(\mathrm{L} / \mathrm{mg})$ & 72.3 & 75.0 \\
\hline $\mathrm{R}_{\mathrm{L}}$ & 0.014 & 0.013 \\
\hline $\mathrm{r}^{2}$ & 0.999 & 0.992 \\
\hline Freundlich model & & \\
\hline $\mathrm{n}$ & 1.656 & 1.490 \\
\hline $\mathrm{K}_{\mathrm{f}}$ & 3.480 & 3.551 \\
\hline $\mathrm{r}^{2}$ & 0.861 & 0.884 \\
\hline Nerst model & & \\
\hline $\mathrm{k}_{\mathrm{d}}$ & 0.604 & 0.671 \\
\hline $\mathrm{r}^{2}$ & 0.861 & 0.884 \\
\hline
\end{tabular}

\section{IODINE NUMBER}

Iodine number is a relative indicator of porosity in an activated carbon. Iodine adsorptions are commonly used method to characterize activated carbon performance. The information on pore size and surface area can be obtained from the characteristics of activated carbon. Iodine is a small sized molecule so it indicates the capacity of carbon to adsorb smaller molecules and its adsorption is restricted to micro-pores [33]. The values obtained showed increase in iodine number from 50.76 to 94.53 as temperature increases $700^{\circ} \mathrm{C}$ to $900^{\circ} \mathrm{C}$.

\section{CONCLUSION}

The results of this study showed that activated carbon can be conveniently obtained from sea snail shell waste for the adsorption of dye in aqueous solution. It was found that adsorption of methylene blue reached maximum uptake of $80.60 \%$ with $0.5 \mathrm{~g}$. The physical properties are comparable to activated carbon obtained from other agricultural wastes. The pseudo second order kinetic model, fits the adsorption process well with the highest correlation coefficient of 0.998. This shows that chemical adsorption is the rate limiting mechanism. The adsorption of methylene blue is well described as monolayer since the Langmuir model has relatively high correlation coefficient $\mathrm{R}^{2}>0.998$. The activated carbon prepared from sea snail shell showed affinity for methylene blue dye adsorption.

\section{Acknowledgment}

The authors thank Niger Delta University and Department of Chemistry for providing laboratory facilities during the research. 


\section{REFERENCES}

[1] Lofty, H.R., Mishairabgwi, J., and Mutwa, M.M., (2012) 'The preparation of activated carbon from agroforestry waste for wastewater treatment' African Journal of Pure and Applied Chemistry. 6(11) pp 149-156.

[2] Baker F. S., Miller C. E., Repic A. J., and Tolles E. D., (1992) Activated Carbon. Kirk - Othmer Encyclopedia of Chemical Technology. 4 pp. 1015-1037.

[3] El-Hendway A. A., (2003) Influence of $\mathrm{HNO}_{3}$ Oxidation on the Structured and Adsorptive Properties of Corncob Activated carbon. Carbon 41: pp. 713 -722.

[4] Chu , W., (2001)'Dye removal from textile dye waste waters using recycled alum sludge' . Water Research 35(13) .pp 3147-3152)

[5] Fermendes, C., Lalithu, V.S., and Kao, K.V.K., (1997) 'Enhancing effect of malachite green on the development of hepatic pre-neo- plastic lesions induced by nitrosodiethylamine in rats' Carcinogenesis. 12, pp B39-R45.

[6] Henderson, A.L., Schmit, T.C., heinze, T.M and Cerniglia, C.E (1997) 'Reduction of malachite green to leucomalachite green by intestinal bacteria' Applied Environmental Microbiology, 63, pp 4099. 4101

[7] Yuh-Shua H., Malarvizhi, R., and Sulochana, N., (2009) Equilibrium Isotherm studies of Methylene blue adsorption onto Activated Carbon Prepared from Delonix regia Pods'. Journal of Environmental Protection Science'. 3. pp 111-116

[8] Churhly, J.H.,(1994) 'Removal of sewage effluent -the use of a full scale ozone plants' . Water Science and technology 30(3) pp 275-284.

[9] Stern, S.R., Azpyikowicz and Rodighiro, I., (2005) Aerobic treatment of textile dyeing wastewater . Water Science and Technology 47 (11) pp 55-59

[10] Rengarag S, Seung-Hyeon Moon, Sivabalan S, Arabindd B. and Murugesan V. (2002) 'Agricultural Solid Waste for the removal of Organics: Adsorption of Phenol from water and waste water by Palm seed coat Activated Carbon'. Waste Management; 22 pp 543-548.

[11] Laine J, Calafat A. and Labady M .(1989) 'Preparation and Characterization of Activated Carbons from Coconut Shell Impregnated with Phosphoric Acid'. Carbon 27 pp. 191-195.

[12] Rodriznez- Reinoso S, Molina Sobia M. and Gazalez G.C. (2001) 'Preparation of Activated CarbonSepiolite Pellets'. Carbon, 39, pp 771-785.

[13] Ademuliyi, F.T., Gumus, R.H., Adejini, S.M., and Jasem, O.T. 2009) 'Effect of process condition on the characterization of activated carbon from waste Nigeria bamboo'. Journal of the Nigerian Society of Chemical Engineers, 24, pp 83-94

[14] Raveenbra R.S, Prashanth, P.A., Malini, B.R and Nagabhushana, B.M (2015) Adsorption of Eriocrome black - T azo Dye from Aqueous solution on Low cost Activated Carbon prepared from Tridax procumbens. Research Journal of Chemical Sciences. 5 (3) pp 9-13

[15] Elsheikh A, Newman A, Al- Daffa and Crosswell N; (2003)'Characterization of Activated Carbon prepared from a single cultivar of Jordanian Olive stones by chemical and Physico chemical techniques'. Journal of Analytical Applied Pyrolysis; 30.pp 1-16.

[16] Gumus, R.H., Wauton, I., and Aliu, A.M., (2012) 'Investigation of the effect of Chemical Activation and characterization of bone char: Cow bone'. Journal of Engineering and Applied Science . 4. pp 3445

[17] Gumus, R,H., and Okpeku I., (2015) 'Production of Activated carbon and characterization from snail shell waste (Helix pomatia)'. Advances in chemical Engineering and Science 5, pp 51-61

[18] Perez-Martin, A.B., Messegues, Zapata, V., Ortuno, J.F., Aquilar, M., Saez, J., Llorens, M.,(2007) 'Removal of cadmium from aqueous solution by adsorption onto orange waste'. Journal of . Hazard. Matter. B139, pp 122-131.

[19] Mohanty, K., Tha, M., Melkap, B.C., Biswas, M.N.,(2005)' Removal of chromium II from dilute aqueous solution by activated carbon developed from Terminalia arjuna nuts activated with zinc chloride'. Chemical Engineering Science. 60, pp 3049-3059.

[20] Sivakumar, P., and Palanizamy., P.N.,(2009) 'Adsorption studies of basic Red 29 by A non conventional Activated carbon prepared from (Euphorbia Antiquarum L.)' International Journal of Chem Tech Research. 1(3) pp 502-510. 
[21] Badmas, M.A.O., Audu, T.O.K and Anyata, B.U., (2007) 'Removal of lead ion from Industrial waste water by Activated carbon prepared from periwinkle shells (Typononus fuscatus)' Turkish Journal of . Engineering, and Environmental Science. 31, pp 251-268

[22] Sugumaran, P., Priya Susan, V., Ravichandran, P and Seshadri, S., (2012) 'Production and Characterization of Activated carbon from banana Empty Fruit bunch and Delonix regia fruit Pod. Journal of sustainable Energy \& Environment'. 3 pp 125-132.

[23] Kakalanga, K., Nickel pollution abatement from landfill leachate using biomaterials. Master Thesis. (2013) Cape peninsula University of Technology p 56

[24] Ekpete, M., Horsfall, Jnr and Tarawou, T (2010) Potential of fluted pumkin and commercial Activated carbons for Phenol Removal in Aqueous Systems. ARPN Journal of Engineering and Applied Sciences. 5. (3) pp 39

[25] Aguila, D.M.M and Ligaray, M.V., (2015) Adsorption of Eriochrome black $\mathrm{T}$ on $\mathrm{MnO}_{2}$-Coated Zeolite. International Journall of Environmental Science and Development. 6 (11) pp 824-827

[26] Weber, W.J., and Morris, J.C., (1963) 'Preliminary appraisal of advanced waste treatment process', Proceeding of International. Conference, Advances in Water Pollution Resource. 2, pp 231-241

[27] Ozcan , A.S Erdem, B, Ozcan , A. (2005)`Adsorption of acid blue 913 from aqueous solutions onto B TMA -bentonite'. Colliod Surface A, 266 pp 73-81

[28] Okeola, F.O., and Odebunmi, E.O., (2010) 'Freundlich and Langmuir Isotherm parameters for Adsorption of methylene blue by Activated Carbon Derived from Agrowastes' . Advances in Natural and Applied Sciences 4(3) pp 281-288.

[29] Satish M., Vanraj, B.C. and Manocha, L.M. (2002) 'Porosity development on activated of char from dry and wet bamboo wood'. Carbon Science 3(3) pp 133-141.

[30] Opeolu, B.O., Bamaghose, O., and Fatoki, O.S., (2011)'Zinc abatement from simulated and industrial waste waters using sugarcane biomass'. Water SA p 37.

[31] Yakubu, M., Gumel, K., and Abdullah, M.S., (2008) 'Use of activated carbon from date seed to treat textile and tannery effluents'. African Journal of Science and Technology. 9 (91) pp 31-40

[32] Longhinoti, E., Pozza, F., Furian, L., Sandez, M., King, M Laranjeira, MCM., and Favero, V.T., (1998) 'Adsorption of Anionic Dyes on the Bipolymer chitin'. Journal of . Brazilan. Chemical Society 19. (51) pp 435-440

[33] Cleiton, N. A., Guerreiro M.C., (2011) 'Estimation of surface area and pore volume of activated carbons by methylene blue and iodine numbers', Quím. Nova 34 (3) p 13

\section{AUTHOR}

Rhoda Habor Gumus, is a reader in Niger Delta University., in Chemical Engineering. She graduated with a Chemical Engineering, Master Of Technology degree in 1988 at the River State University of Science and Technology, Port Harcourt. Nigeria, and with a $\mathrm{PhD}$ at Loughborough University, United Kingdom (2005). She became a registered member of the Council for the Regulation of Engineering in Nigeria (COREN) in 2008. Her specialization is model simulation and Reactor design, and research interest in product design and Environmental Engineering.

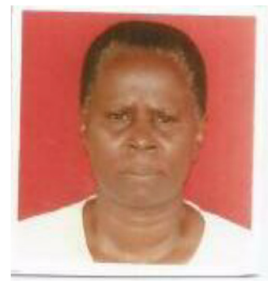

